\title{
Casa Parameters of Mithun Semen Treated with Melatonin
}

\author{
Perumal Ponraj ${ }^{1 *}$, Kishore Kumar Baruah ${ }^{2}$, Kobu Khate ${ }^{1}$, Neeraj Srivastava ${ }^{3}$, Jeetendra \\ Singh Rajoriya ${ }^{4}$, Sukkum Chang ${ }^{1}$
}

\begin{abstract}
${ }^{1}$ Animal Reproduction Lab, ICAR-National Research Centre on Mithun, Jharnapani, Nagaland - 797106 India; ${ }^{2} I C A R-N a t i o n a l ~ R e s e a r c h$ Centre on Pig, Rani, Guwahati, Assam, India; ${ }^{3} I C A R$ - Central Institute for Research on Cattle, Meerut, UP, India; ${ }^{4}$ Department of AR GO, College of Veterinary Science E' Animal Husbandry, Rewa, $M P$, India.
\end{abstract}

\begin{abstract}
A study was conducted to measure the effect of melatonin (MT) on motility and velocity parameters of mithun semen by Computer Assisted Sperm Analyser (CASA) in different seasons. Total numbers of 80 ejaculates ( 20 ejaculates in each season) were collected twice a week from mithun bulls and were split into five equal aliquots, diluted with the Tris Egg Yolk Citrate (TEYC) extender. Group 1: semen without additives (control), group 2 to group 6: semen was diluted with 1, 2, 3, 4 and $5 \mathrm{mM}$ of melatonin, respectively. CASA parameter such as Forward Progressive Motility (FPM), Total Motility (TM), Curvilinear Velocity (VCL), Straight Line Velocity (VSL), Average Path Velocity (VAP), Linearity (LIN), Straightness (STR), Amplitude of Lateral Head displacement (ALH) and Beat / Cross Frequency (BCF) were measured after 12 hrs of incubation at $5^{\circ} \mathrm{C}$. Blood samples were collected in different seasons to estimate the melatonin. The results revealed that these parameters were varied significantly $(\mathrm{p}<0.05)$ among the different experimental groups and among the seasons. Further, MT at $3 \mathrm{mM}$ has significant improvement than other treatment groups stored in in-vitro at different seasons. Additionally, spring season has highest value followed by winter and autumn season, whereas lower values were in summer season. Melatonin concentration was higher in winter season and lowest was in summer season. The result of the study indicated that the melatonin protects CASA parameters, varied in different seasons. It was concluded that ejaculates from spring and winter season has significantly higher CASA parameters in mithun.
\end{abstract}

Keywords $\mid$ melatonin, mithun, computer assisted sperm analysis, seasons

Editor | M. Saminathan (M.V.Sc), Division of Pathology, ICAR-Indian Veterinary Research Institute (ICAR-IVRI), Izatnagar, Bareilly, Uttar Pradesh, India Special Issue | 2, 2016 "Emerging Challenges and Opportunities in Veterinary Research for Improvement of Animal Health".

Received | January 28, 2016; Revised | March 25, 2016; Accepted | March 28, 2016; Published | April 06, 2016

${ }^{*}$ Correspondence | Perumal Ponraj, Scientist, Animal Reproduction Lab, ICAR-National Research Centre on Mithun, Jharnapani, Nagaland-797106, India;

Email: perumalponraj@gmail.com

Citation | Ponraj P, Baruah KK, Khate K, Srivastava N, Rajoriya JS, Chang S (2016). Casa parameters of mithun semen treated with melatonin. Adv. Anim. Vet. Sci. 4(2s): 5-12.

DOI | http://dx.doi.org/10.14737/journal.aavs/2016/4.2s.5.12

ISSN (Online) | 2307-8316; ISSN (Print) | 2309-3331

Copyright (c) 2016 Ponraj et al. This is an open access article distributed under the Creative Commons Attribution License, which permits unrestricted use, distribution, and reproduction in any medium, provided the original work is properly cited.

\section{INTRODUCTION}

$\mathrm{S}^{\mathrm{c}}$ easonality is one of the most important factors that influence the reproduction and production potential (Mathevon et al., 1998). Semen quality parameters are significantly influenced by the seasons. Thermal tolerance capacity of indigenous cattle is better than exotic cattle indicated good quality semen and lower sperm abnormalities (Rajoriya et al., 2013). The testes are extremely sensitive to high ambient temperature, resulting in degenerative changes characterized by reduction in testicular size, change in its structure, consistency and functions (McEntee, 1990). It is poorly understood that to what extent the seasonal effect on the reproduction performance in mithun species. Liquid storage of semen at refrigerator temperature is used to decrease metabolism and to maintain quality and viability of the sperm for an extended period of time. But the sperm quality is decreased in the extended period of 
storage. Antioxidants are naturally present in mammalian semen to counteract the reactive oxygen species (ROS) to protect the sperm (Akhter et al., 2011). However, the concentration of these antioxidants is decreased during the process of dilution and preservation (Kumar et al., 2011). Hence synthetic or natural antioxidants should be included in the semen extender at the time of dilution (Perumal et al., 2013). Thus enhance the quality in chilled liquid semen preservation (Perumal et al., 2013; Perumal et al., 2015).

Melatonin is an indole derivative of endogenous compound secreted rhythmically from the pineal gland in the brain and influences in the circadian clock and seasonal reproduction in mammals (Reiter, 1991). Melatonin and its metabolites act as the powerful antioxidant and antiapoptotic agent (Reiter et al., 1998). It has been reported that melatonin has potency twice against peroxyl radicals as that of vitamin $\mathrm{E}$ in action (Pieri et al., 1994) and also it is more effective in scavenging of the hydroxyl radicals than mannitol and reduced glutathione (Hardeland et al., 1993). Melatonin is associated with mitochondrial membrane potential (Acuna-Castroviejo et al., 2011), ATP production (Chen et al., 1994), interaction with calmodulin (Tash et al., 1983), stimulates cellular influx of Ca2+ into sperm cells (Delgadillo et al., 1994) and cyclic AMP (cAMP) stimulator (Yung et al., 1995), through which the melatonin stimulate the sperm to get higher motility and velocity.

Antioxidant effects of melatonin on seminal parameters were studied in various species (Ram: Casao et al., 2010; Ashrafi et al., 2011, Boar: Martin-Hildago et al., 2011, Bull: Ashrafi et al., 2013, Mithun: Perumal et al., 2013; Perumal et al., 2015) in refrigerated or in the unfrozen storage. Literatures study revealed no report on effect of season and melatonin on mobility and velocity parameters in mithun species. Therefore, the present study was designed to measure the motility and velocity parameters in semen extended with melatonin at different concentration in liquid refrigerated preservation at different seasons in mithun.

\section{MATERIAL AND METHODS}

\section{Experimental Animals}

Ten apparently healthy mithun bulls of approximately 4 to 6 year of age with good body condition (score 5-6) were selected from the herd of mithun farm, ICAR-NRC on Mithun, Jharnapani, Nagaland India, which is located between $25^{\circ} 54^{\prime} 30^{\prime \prime}$ North Latitude and $93^{\circ} 44^{\prime} 15^{\prime \prime}$ East Longitude and at an altitude range of 250-300 feet Mean Sea Level. Month wise THI was calculated and the year has been divided in to four seasons as per the THI (winter: 54.41, spring: 63.50, summer: 76.05 and autumn: 74.00). These animals were maintained under uniform feeding, housing and managemental conditions. The feeding practices were followed as per the farm schedule. Semen was collected from the animals through trans-rectal massage method.

\section{Semen Collection and Processing}

The collection seasons were split into four viz. spring (February to April), summer (May to July), autumn (August to October) and winter (November to January). Total numbers of 80 ejaculates (20 ejaculates from each season) were collected from the mithun bulls twice a week. Immediately after collection, the samples were kept in a water bath at $37^{\circ} \mathrm{C}$ and evaluated basic seminal parameters. After the preliminary evaluations, samples were subjected to the initial dilution with pre-warmed $\left(37^{\circ} \mathrm{C}\right) \mathrm{TEYC}$. The partially diluted samples were then brought to the laboratory in an insulated flask containing warm water $\left(37^{\circ} \mathrm{C}\right)$ for further processing. Each ejaculate was split into six equal aliquots and diluted with the TEYC extender with melatonin. Group 1: semen without additives (control), group 2 to group 6: semen with 1,2,3, 4 and $5 \mathrm{mM}$ of melatonin, respectively. Diluted semen samples were kept in glass tubes and cooled from 37 to $5^{\circ} \mathrm{C}$, at a rate of $0.2-0.3^{\circ} \mathrm{C} / \mathrm{min}$ in a cold cabinet and maintained at $5^{\circ} \mathrm{C}$ during liquid storage for up to a $12 \mathrm{hrs}$ period of the experiment. The motility and velocity parameters were estimated by image CASA analyzer as per standard procedure for different seasons.

\section{Computer Assisted Sperm Analysis}

The sperm motility and velocity parameters were evaluated by Hamilton Thorne Sperm Analyser, version IVOS 11 (HTM-IVOS, Version 10.8, Hamilton Thorne Research, Beverly, MA, USA). This CASA system consists of a phase-contrast microscope, camera, mini-thermal heating stage, image digitizer and computer saving and analyzing the data. The software settings were arranged as follows. Chamber type: Leja 4, temperature of analysis $\left({ }^{\circ} \mathrm{C}\right): 37.0$, fields acquired: 10, frame rate $(\mathrm{Hz}): 60$, number of frames: 30, minimum static contrast: 35 , minimum cell size (pixels): 5, STR (\%): 70, VAP cut - off $(\mu \mathrm{m} / \mathrm{s}): 30$, Prog.min $\operatorname{VAP}(\mu \mathrm{m} / \mathrm{s}): 50$, VSL cut-off $(\mu \mathrm{m} / \mathrm{s}): 15$, cell intensity: 80 and magnification: 1.89 .

After semen collection, the sperm concentration was first estimated using a phase-contrast microscope (Nikon, Eclipse $80 \mathrm{i} ; 400 \times$ magnification). $25 \mu \mathrm{L}$ of semen was diluted into $50-100 \mu \mathrm{L}$ of Tris (formulated for bull semen) and $5 \mu \mathrm{L}$ of this diluted semen was loaded into a pre-warmed dual chamber disposable Leja slide and was allowed to settle on the minitherm heating stage $\left(37^{\circ} \mathrm{C}\right)$ before the analysis. The following parameters such as percentage of TM, FPM, velocity of rapid, medium, slow and static, VAP $(\mu \mathrm{m} / \mathrm{sec})$, VSL $(\mu \mathrm{m} / \mathrm{sec}), \operatorname{VCL}(\mu \mathrm{m} / \mathrm{sec})$, ALH $(\mu \mathrm{m}), \mathrm{BCF}(\mathrm{Hz})$, STR $(\%)$ and LIN $(\%)$ were measured. A minimum of 200 spermatozoa from at least two different 
Table 1: Mean ( \pm S.E.) total motility, Forward Progressive Motility and velocity of rapid and static for mithun semen following storage at $5^{\circ} \mathrm{C}$ for different seasons

\begin{tabular}{|c|c|c|c|c|c|}
\hline \multirow[t]{2}{*}{ CASA Parameters } & \multirow[t]{2}{*}{ Additives } & \multicolumn{4}{|l|}{ Seasons } \\
\hline & & Winter & Spring & Summer & Autumn \\
\hline \multirow[t]{6}{*}{ Total Motility } & Control & $71.70 \pm 1.88^{\mathrm{bB}}$ & $75.10 \pm 1.97^{\mathrm{bcB}}$ & $62.30 \pm 2.44^{\mathrm{cA}}$ & $65.45 \pm 2.40^{\mathrm{cA}}$ \\
\hline & MT $1 \mathrm{mM}$ & $73.75 \pm 1.84^{\mathrm{bcB}}$ & $75.30 \pm 2.12^{\mathrm{bcB}}$ & $67.80 \pm 2.21^{\mathrm{dA}}$ & $68.40 \pm 2.19^{\mathrm{cdA}}$ \\
\hline & MT $2 \mathrm{mM}$ & $74.85 \pm 1.94^{\mathrm{cB}}$ & $77.40 \pm 2.10^{\mathrm{caB}}$ & $67.00 \pm 2.21^{\mathrm{dA}}$ & $70.40 \pm 1.89^{\mathrm{dA}}$ \\
\hline & MT $3 \mathrm{mM}$ & $77.85 \pm 1.80^{\mathrm{dBC}}$ & $79.70 \pm 1.96^{\mathrm{dC}}$ & $70.60 \pm 1.68^{\mathrm{dA}}$ & $75.65 \pm 1.63^{\mathrm{eB}}$ \\
\hline & MT 4 mM & $72.25 \pm 1.76^{\mathrm{bcC}}$ & $72.35 \pm 1.54^{\mathrm{bC}}$ & $57.35 \pm 1.70^{\mathrm{bA}}$ & $60.90 \pm 1.69^{\mathrm{bB}}$ \\
\hline & MT $5 \mathrm{mM}$ & $65.05 \pm 1.45^{\mathrm{aC}}$ & $68.80 \pm 1.50^{\mathrm{aD}}$ & $50.80 \pm 1.29^{\mathrm{aA}}$ & $56.80 \pm 1.65^{\mathrm{aB}}$ \\
\hline \multirow{6}{*}{$\begin{array}{l}\text { Forward Progres- } \\
\text { sive Motility }\end{array}$} & Control & $28.90 \pm 1.97^{\mathrm{abB}}$ & $33.85 \pm 2.38^{\mathrm{bcC}}$ & $19.80 \pm 2.05^{\mathrm{aA}}$ & $29.35 \pm 1.86^{\mathrm{cB}}$ \\
\hline & MT $1 \mathrm{mM}$ & $30.40 \pm 2.17^{\mathrm{abBC}}$ & $32.10 \pm 2.46^{\mathrm{abC}}$ & $24.00 \pm 2.30^{\mathrm{bcA}}$ & $26.65 \pm 2.54^{\mathrm{bcAB}}$ \\
\hline & MT $2 \mathrm{mM}$ & $32.60 \pm 2.13^{\mathrm{bcB}}$ & $38.80 \pm 2.40^{c C}$ & $26.30 \pm 2.28^{\mathrm{cA}}$ & $28.75 \pm 2.32^{\mathrm{cAB}}$ \\
\hline & MT $3 \mathrm{mM}$ & $35.50 \pm 2.34^{\mathrm{cB}}$ & $38.25 \pm 2.42^{\mathrm{cB}}$ & $27.65 \pm 2.10^{\mathrm{cA}}$ & $34.50 \pm 2.24^{\mathrm{dB}}$ \\
\hline & MT $4 \mathrm{mM}$ & $32.65 \pm 2.22^{\mathrm{bcB}}$ & $34.15 \pm 2.48^{\mathrm{bcB}}$ & $20.35 \pm 2.04^{\mathrm{abA}}$ & $23.65 \pm 2.27^{\mathrm{abA}}$ \\
\hline & MT $5 \mathrm{mM}$ & $26.20 \pm 2.50^{\mathrm{aB}}$ & $27.85 \pm 2.12^{\mathrm{aB}}$ & $17.95 \pm 1.87^{\mathrm{aA}}$ & $21.50 \pm 2.44^{\mathrm{aA}}$ \\
\hline \multirow[t]{6}{*}{ Rapid velocity } & Control & $60.15 \pm 3.06^{\mathrm{abBC}}$ & $67.70 \pm 2.91^{\mathrm{bC}}$ & $49.20 \pm 3.09^{\mathrm{bcA}}$ & $54.80 \pm 3.38^{\mathrm{bcAB}}$ \\
\hline & MT $1 \mathrm{mM}$ & $65.05 \pm 2.95^{\mathrm{bcC}}$ & $68.40 \pm 2.50^{\mathrm{bC}}$ & $48.10 \pm 2.49^{\mathrm{bcA}}$ & $57.50 \pm 2.86^{\mathrm{bcB}}$ \\
\hline & MT $2 \mathrm{mM}$ & $70.90 \pm 2.53^{\mathrm{cdB}}$ & $72.35 \pm 2.61^{\mathrm{bcB}}$ & $53.05 \pm 3.84^{\mathrm{cdA}}$ & $58.70 \pm 2.91^{\mathrm{cA}}$ \\
\hline & MT 3 mM & $77.15 \pm 1.73^{\mathrm{dBC}}$ & $78.25 \pm 2.06^{\mathrm{cC}}$ & $61.25 \pm 2.76^{\mathrm{dA}}$ & $73.75 \pm 2.23^{\mathrm{dB}}$ \\
\hline & MT $4 \mathrm{mM}$ & $63.85 \pm 2.59^{\mathrm{abB}}$ & $65.80 \pm 2.72^{\mathrm{bB}}$ & $43.40 \pm 2.66^{\mathrm{abA}}$ & $49.70 \pm 3.10^{\mathrm{bA}}$ \\
\hline & MT $5 \mathrm{mM}$ & $56.90 \pm 3.10^{\mathrm{aB}}$ & $56.70 \pm 2.97^{\mathrm{aB}}$ & $39.10 \pm 2.73^{\mathrm{aA}}$ & $38.90 \pm 2.98^{\mathrm{aA}}$ \\
\hline \multirow[t]{6}{*}{ Static velocity } & Control & $13.45 \pm 2.58^{\mathrm{abA}}$ & $14.70 \pm 2.03^{\mathrm{abAB}}$ & $20.25 \pm 2.27^{\mathrm{abC}}$ & $19.40 \pm 2.99^{\mathrm{bBC}}$ \\
\hline & MT $1 \mathrm{mM}$ & $14.80 \pm 2.56^{\mathrm{b}}$ & $13.50 \pm 2.43^{\mathrm{ab}}$ & $17.55 \pm 2.94^{\mathrm{ab}}$ & $16.45 \pm 2.77^{\mathrm{ab}}$ \\
\hline & MT $2 \mathrm{mM}$ & $12.20 \pm 1.65^{\mathrm{ab}}$ & $12.90 \pm 2.09^{\mathrm{a}}$ & $14.35 \pm 2.69^{\mathrm{a}}$ & $15.25 \pm 2.73^{\mathrm{ab}}$ \\
\hline & MT $3 \mathrm{mM}$ & $9.10 \pm 1.81^{\mathrm{aA}}$ & $10.15 \pm 2.07^{\mathrm{aA}}$ & $15.25 \pm 2.59^{\mathrm{aB}}$ & $10.65 \pm 2.26^{\mathrm{aA}}$ \\
\hline & MT $4 \mathrm{mM}$ & $16.30 \pm 2.33^{\mathrm{bA}}$ & $18.60 \pm 2.74^{\mathrm{bAB}}$ & $22.70 \pm 2.34^{\mathrm{bB}}$ & $21.05 \pm 3.07^{\mathrm{bAB}}$ \\
\hline & MT $5 \mathrm{mM}$ & $16.25 \pm 2.62^{\mathrm{bA}}$ & $18.65 \pm 2.91^{\mathrm{bA}}$ & $31.25 \pm 3.16^{\mathrm{cB}}$ & $19.90 \pm 3.16^{\mathrm{bA}}$ \\
\hline
\end{tabular}

Within columns means with different letters $(\mathrm{a}, \mathrm{b}, \mathrm{c}, \mathrm{d})$ differ significantly $(P<0.05)$

Within rows means with different letters $(\mathrm{A}, \mathrm{B}, \mathrm{C}, \mathrm{D})$ differ significantly $(P<0.05)$

drops of each sample were analyzed from each specimen. The number of objects was incorrectly identified as spermatozoa were manually removed and final analysis was done for each sample.

\section{Blood Collection, Plasma Separation and} Estimation OF THE Hormone

Seven $\mathrm{ml}$ of blood samples were collected randomly immediately after semen collection from the external jugular vein in tubes with heparin anticoagulant for different seasons. Plasma was separated from blood by centrifugation at $3500 \mathrm{~g}$ at $4^{\circ} \mathrm{C}$ for $20 \mathrm{~min}$. The plasma was stored in frozen state at $-80^{\circ} \mathrm{C}$ until further analysis. Melatonin was estimated with radio immuno assay kit (Anand Brothers, New Delhi, India).

\section{Statistical Analysis}

The results were analysed statistically and expressed as the mean \pm S.E.M. Means were analyzed by one way analysis of variance (ANOVA), followed by the Tukey's post hoc test to determine significant differences between the different seasons with additives or without additive and between the treatment and control groups on different seasons on the sperm mobility and velocity parameters using the SPSS/ PC computer program (version 15.0; SPSS, Chicago, IL). Differences with values of $\mathrm{p}<0.05$ were considered to be statistically significant after arcsine transformation of percentage data.

\section{RESULTS AND DISCUSSION}

In the present study, the CASA parameters such as TM (Table 1), FPM (Table 1), velocity of rapid and static (Table 1), VAP (Table 2), VSL (Table 2), VCL (Table 2), ALH (Table 3), BCF (Table 3), STR (Table 3) and LIN (Table 3$)$ were significantly $(\mathrm{p}<0.05)$ higher in melatonin 3 $\mathrm{mM}$ treated group as compared to control and other MT treated groups. Moreover, MT $3 \mathrm{mM}$ treated and other experimental groups have significantly $(\mathrm{p}<0.05)$ higher percentage in the spring followed by winter and least was 
Table 2: Mean ( \pm S.E.) average path velocity, Straight Line Velocity and Curve Linear Velocity of mithun sperm following storage at $5^{\circ} \mathrm{C}$ for different seasons

\begin{tabular}{|c|c|c|c|c|c|}
\hline \multirow[t]{2}{*}{ CASA parameters } & \multirow[t]{2}{*}{ Additives } & \multicolumn{4}{|l|}{ Seasons } \\
\hline & & Winter & Spring & Summer & Autumn \\
\hline \multirow{6}{*}{$\begin{array}{l}\text { Average Path Ve- } \\
\text { locity }\end{array}$} & Control & $112.42 \pm 5.35^{\mathrm{ab}}$ & $120.34 \pm 5.17^{\mathrm{ab}}$ & $103.54 \pm 4.65^{\mathrm{ab}}$ & $109.11 \pm 5.13^{\mathrm{ab}}$ \\
\hline & MT $1 \mathrm{mM}$ & $111.02 \pm 4.60^{\mathrm{abB}}$ & $125.86 \pm 4.18^{\mathrm{abB}}$ & $91.82 \pm 3.98^{\mathrm{abA}}$ & $110.44 \pm 4.87^{\mathrm{abB}}$ \\
\hline & MT $2 \mathrm{mM}$ & $130.51 \pm 5.43^{\mathrm{bcB}}$ & $134.90 \pm 4.51^{\mathrm{bB}}$ & $105.87 \pm 5.78^{\mathrm{abA}}$ & $111.07 \pm 5.09^{\mathrm{abA}}$ \\
\hline & MT $3 \mathrm{mM}$ & $138.02 \pm 4.29^{\mathrm{cB}}$ & $139.53 \pm 4.82^{\mathrm{bB}}$ & $111.13 \pm 5.13^{\mathrm{bA}}$ & $132.61 \pm 4.30^{\mathrm{bAB}}$ \\
\hline & MT $4 \mathrm{mM}$ & $122.97 \pm 5.32^{\mathrm{abcB}}$ & $126.25 \pm 5.42^{\mathrm{abB}}$ & $86.25 \pm 3.25^{\mathrm{aA}}$ & $105.86 \pm 5.09^{\mathrm{aAB}}$ \\
\hline & MT $5 \mathrm{mM}$ & $101.94 \pm 4.91^{\mathrm{aAB}}$ & $112.67 \pm 4.87^{\mathrm{aB}}$ & $92.07 \pm 5.27^{\mathrm{abA}}$ & $96.96 \pm 4.37^{\mathrm{aAB}}$ \\
\hline \multirow{6}{*}{$\begin{array}{l}\text { Straight Line } \\
\text { Velocity }\end{array}$} & Control & $78.75 \pm 4.26^{\mathrm{abB}}$ & $87.00 \pm 4.47^{\mathrm{abB}}$ & $58.99 \pm 2.98^{\mathrm{abA}}$ & $74.48 \pm 3.68^{\mathrm{abB}}$ \\
\hline & MT $1 \mathrm{mM}$ & $86.97 \pm 4.28^{\mathrm{bcAB}}$ & $90.69 \pm 4.70^{\mathrm{abB}}$ & $72.78 \pm 4.82^{\mathrm{bA}}$ & $77.63 \pm 4.53^{\mathrm{abAB}}$ \\
\hline & MT $2 \mathrm{mM}$ & $90.49 \pm 3.83^{\mathrm{bcBC}}$ & $94.57 \pm 5.11^{\mathrm{bC}}$ & $70.67 \pm 4.23^{\mathrm{abA}}$ & $77.26 \pm 4.29^{\mathrm{abAB}}$ \\
\hline & MT $3 \mathrm{mM}$ & $95.87 \pm 4.25^{\mathrm{cB}}$ & $95.10 \pm 3.88^{\mathrm{bB}}$ & $74.50 \pm 4.21^{\mathrm{bA}}$ & $88.38 \pm 4.76^{\mathrm{bAB}}$ \\
\hline & MT $4 \mathrm{mM}$ & $77.24 \pm 4.23^{\mathrm{abB}}$ & $85.49 \pm 3.88^{\mathrm{abC}}$ & $55.85 \pm 2.80^{\mathrm{aA}}$ & $71.61 \pm 4.58^{\mathrm{abAB}}$ \\
\hline & MT $5 \mathrm{mM}$ & $69.61 \pm 3.69^{\mathrm{aAB}}$ & $80.13 \pm 4.27^{\mathrm{aB}}$ & $66.72 \pm 4.61^{\mathrm{abA}}$ & $68.66 \pm 4.05^{\mathrm{aAB}}$ \\
\hline \multirow{6}{*}{$\begin{array}{l}\text { Curve Linear } \\
\text { Velocity }\end{array}$} & Control & $207.59 \pm 7.19^{\mathrm{abAB}}$ & $225.46 \pm 7.09^{\mathrm{aB}}$ & $179.87 \pm 5.19^{\mathrm{abA}}$ & $202.97 \pm 6.94^{\mathrm{aAB}}$ \\
\hline & MT $1 \mathrm{mM}$ & $209.86 \pm 6.55^{\mathrm{abAB}}$ & $236.75 \pm 5.82^{\mathrm{abB}}$ & $195.76 \pm 5.83^{\mathrm{abA}}$ & $217.14 \pm 6.02^{\mathrm{abAB}}$ \\
\hline & MT $2 \mathrm{mM}$ & $242.67 \pm 7.34^{\mathrm{bcAB}}$ & $253.26 \pm 6.05^{\mathrm{bB}}$ & $202.70 \pm 8.15^{\mathrm{bA}}$ & $249.92 \pm 5.25^{\mathrm{bcB}}$ \\
\hline & MT $3 \mathrm{mM}$ & $253.84 \pm 5.08^{c}$ & $254.63 \pm 5.23^{\mathrm{b}}$ & $214.33 \pm 6.85^{\mathrm{b}}$ & $255.62 \pm 6.16^{c}$ \\
\hline & MT $4 \mathrm{mM}$ & $200.34 \pm 6.82^{\mathrm{aAB}}$ & $228.70 \pm 7.16^{\mathrm{aB}}$ & $173.83 \pm 4.85^{\mathrm{abA}}$ & $220.94 \pm 6.74^{\mathrm{abcB}}$ \\
\hline & MT $5 \mathrm{mM}$ & $182.26 \pm 6.29^{\mathrm{aAB}}$ & $202.92 \pm 6.22^{\mathrm{aB}}$ & $160.00 \pm 7.83^{\mathrm{aA}}$ & $197.84 \pm 6.42^{\mathrm{aAB}}$ \\
\hline
\end{tabular}

Within columns means with different letters $(\mathrm{a}, \mathrm{b}, \mathrm{c}, \mathrm{d})$ differ significantly $(P<0.05)$

Within rows means with different letters $(\mathrm{A}, \mathrm{B}, \mathrm{C}, \mathrm{D})$ differ significantly $(P<0.05)$

in summer season. The CASA parameters were increased to MT $3 \mathrm{mM}$ treated group then decreased to MT 4 and $5 \mathrm{mM}$. Additionally, melatonin at $1,2,4$ and $5 \mathrm{mM}$ were inferior to MT $3 \mathrm{mM}$ treatments for these motility parameters and there was a significant $(\mathrm{p}<0.05)$ difference between melatonin at $1,2,4,5 \mathrm{mM}$ and $3 \mathrm{mM}$ for these response at different seasons. Moreover, MT 4 and $5 \mathrm{mM}$ treated groups have significantly $(\mathrm{p}<0.05)$ lower value than untreated control group. The concentration of melatonin in serum on different seasons revealed a significant $(p<0.05)$ difference among the seasons and was significantly $(\mathrm{p}<$ 0.05 ) highest in winter followed by spring, autumn and lowest was in summer season.

The results of inclusion of melatonin has improved the motility and velocity parameters of mithun sperm in different seasons and was higher in spring followed by winter, autumn and lowest was in summer season. The literature study revealed that there was no report on effect of inclusion of MT on CASA parameters in mithun semen in different seasons and to the best of our knowledge; this is the first report on the effect of MT on these CASA profiles in different seasons in mithun semen. However, there was some reports available on effect of MT on semen quality parameters preserved at liquid state upto $30 \mathrm{hrs}$ of incubation (Perumal et al., 2013) and at different seasons (Perumal et al., 2015) and also some studies were conducted on
CASA parameters in mithun semen preservation (Perumal et al., 2014). In the previous studies, it has been reported that MT has improved the semen quality parameters, antioxidant profiles and reduced leakage of intra cellular enzymatic profiles in liquid semen preservation in mithun (Perumal et al., 2013; Perumal et al., 2015). Moreover, it reduced the production malondialdehyde and cholesterol efflux as preserved in liquid state (Perumal et al., 2013; Perumal et al., 2015). However, many authors reported that MT has beneficial effects on preservation of mammalian sperm and improves the velocity and mobility parameters of spermatozoa (Ashrafi et al., 2011; Ashrafi et al., 2013) and also on semen quality parameters (Casao et al., 2010; Ashrafi et al., 2011; Ashrafi et al., 2013; Perumal et al., 2013; Perumal et al., 2015).

Melatonin has improved the velocity and mobility parameters of mithun semen in dose depended manner in different seasons (Casao et al., 2010; Perumal et al., 2013; Perumal et al., 2015) as $3 \mathrm{mM}$ MT is being the most effective and optimum concentration and spring and winter are more suitable seasons. Thus, melatonin in the sperm extender induced higher viability rates, a greater percentage of total motile and progressive motile spermatozoa, a larger number of sperm with higher medium or rapid velocity and elevated intracellular ATP concentrations as reported in the previous studies (Perumal et al., 2013; Perumal et al., 
Table 3: Mean ( \pm S.E.) amplitude of lateral head displacement, Beat Cross Frequency, Straightness and Linearity of mithun sperm following storage at $5^{\circ} \mathrm{C}$ for different seasons

\begin{tabular}{|c|c|c|c|c|c|}
\hline \multirow[t]{2}{*}{ CASA parameters } & \multirow[t]{2}{*}{ Additives } & \multicolumn{4}{|l|}{ Seasons } \\
\hline & & Winter & Spring & Summer & Autumn \\
\hline \multirow{6}{*}{$\begin{array}{l}\text { Amplitude Of Lateral } \\
\text { Head Displacement }\end{array}$} & Control & $9.34 \pm 1.11^{\mathrm{abAB}}$ & $10.30 \pm 1.09^{\mathrm{aB}}$ & $8.70 \pm 1.13^{\mathrm{aA}}$ & $9.50 \pm 1.20^{\mathrm{abAB}}$ \\
\hline & $\mathrm{MT} 1 \mathrm{mM}$ & $10.11 \pm 2.07^{\mathrm{b}}$ & $10.16 \pm 1.03^{a}$ & $9.27 \pm 1.37^{\mathrm{ab}}$ & $9.44 \pm 1.32^{2 \mathrm{~b}}$ \\
\hline & MT $2 \mathrm{mM}$ & $10.10 \pm 0.86^{b}$ & $10.35 \pm 1.88^{\mathrm{a}}$ & $9.10 \pm 1.15^{\mathrm{ab}}$ & $9.79 \pm 1.16^{\mathrm{b}}$ \\
\hline & MT 3 mM & $10.18 \pm 0.99^{b}$ & $14.09 \pm 4.37^{b}$ & $9.71 \pm 1.18^{\mathrm{b}}$ & $9.90 \pm 1.21^{b}$ \\
\hline & MT 4 mM & $9.37 \pm 1.06^{\mathrm{ab}}$ & $9.56 \pm 1.76^{\mathrm{a}}$ & $8.76 \pm 0.99^{\mathrm{ab}}$ & $9.35 \pm 1.08^{\mathrm{ab}}$ \\
\hline & MT $5 \mathrm{mM}$ & $8.90 \pm 1.30^{\mathrm{a}}$ & $9.41 \pm 1.78^{\mathrm{a}}$ & $8.88 \pm 1.10^{\mathrm{ab}}$ & $8.62 \pm 1.18^{\mathrm{a}}$ \\
\hline \multirow[t]{6}{*}{ Beat Cross Frequency } & Control & $25.37 \pm 2.24$ & $26.19 \pm 2.37^{\mathrm{ab}}$ & $22.55 \pm 1.86$ & $23.60 \pm 3.15$ \\
\hline & MT $1 \mathrm{mM}$ & $24.89 \pm 2.33$ & $27.01 \pm 3.15^{\mathrm{ab}}$ & $23.51 \pm 2.26$ & $24.25 \pm 1.89$ \\
\hline & MT $2 \mathrm{mM}$ & $24.80 \pm 2.17^{\mathrm{AB}}$ & $27.30 \pm 2.02^{\mathrm{abB}}$ & $23.76 \pm 1.78^{\mathrm{A}}$ & $24.57 \pm 2.22^{\mathrm{AB}}$ \\
\hline & MT $3 \mathrm{mM}$ & $25.88 \pm 1.64^{\mathrm{A}}$ & $29.96 \pm 2.32^{\mathrm{bB}}$ & $24.07 \pm 2.27^{\mathrm{A}}$ & $24.70 \pm 2.19^{\mathrm{A}}$ \\
\hline & MT $4 \mathrm{mM}$ & $24.50 \pm 2.35^{\mathrm{AB}}$ & $25.22 \pm 2.02^{\mathrm{abB}}$ & $22.86 \pm 2.09^{\mathrm{AB}}$ & $22.01 \pm 1.76^{\mathrm{A}}$ \\
\hline & MT $5 \mathrm{mM}$ & $23.96 \pm 1.76^{\mathrm{AB}}$ & $24.56 \pm 2.00^{\mathrm{aB}}$ & $22.91 \pm 2.30^{\mathrm{AB}}$ & $21.50 \pm 2.09^{\mathrm{A}}$ \\
\hline \multirow[t]{6}{*}{ Straightness } & Control & $66.35 \pm 2.21^{\mathrm{abAB}}$ & $66.75 \pm 2.08^{\mathrm{abB}}$ & $63.70 \pm 2.14^{\mathrm{abA}}$ & $64.45 \pm 1.64^{\mathrm{AB}}$ \\
\hline & MT $1 \mathrm{mM}$ & $65.45 \pm 1.74^{\mathrm{abA}}$ & $69.80 \pm 2.61^{\mathrm{abB}}$ & $64.35 \pm 1.98^{\mathrm{abA}}$ & $64.95 \pm 1.85^{\mathrm{A}}$ \\
\hline & MT $2 \mathrm{mM}$ & $66.65 \pm 2.68^{\mathrm{abAB}}$ & $70.15 \pm 1.86^{\mathrm{bB}}$ & $64.75 \pm 2.06^{\mathrm{abA}}$ & $65.80 \pm 2.94^{\mathrm{AB}}$ \\
\hline & MT $3 \mathrm{mM}$ & $68.55 \pm 2.70^{\mathrm{bAB}}$ & $70.40 \pm 2.57^{\text {ьв }}$ & $67.30 \pm 1.88^{\mathrm{bAB}}$ & $66.00 \pm 2.70^{\mathrm{A}}$ \\
\hline & MT 4 mM & $66.30 \pm 2.07^{\mathrm{ab}}$ & $66.55 \pm 2.68^{\mathrm{ab}}$ & $65.45 \pm 2.14^{\mathrm{ab}}$ & $65.45 \pm 2.24$ \\
\hline & MT $5 \mathrm{mM}$ & $63.15 \pm 2.73^{\mathrm{a}}$ & $66.10 \pm 2.24^{\mathrm{a}}$ & $63.20 \pm 2.03^{a}$ & $64.00 \pm 1.82$ \\
\hline \multirow[t]{6}{*}{ Linearity } & Control & $38.05 \pm 2.16^{\mathrm{abAB}}$ & $38.60 \pm 2.23^{\mathrm{B}}$ & $35.40 \pm 1.89^{\mathrm{abA}}$ & $35.65 \pm 2.01^{\mathrm{A}}$ \\
\hline & MT $1 \mathrm{mM}$ & $38.75 \pm 2.38^{\mathrm{abAB}}$ & $40.65 \pm 3.08^{\mathrm{B}}$ & $34.65 \pm 1.77^{\mathrm{abA}}$ & $36.95 \pm 2.46^{\mathrm{AB}}$ \\
\hline & MT $2 \mathrm{mM}$ & $37.80 \pm 2.12^{\mathrm{abAB}}$ & $41.15 \pm 2.92^{\mathrm{B}}$ & $36.45 \pm 2.25^{\mathrm{abA}}$ & $37.20 \pm 2.71^{\mathrm{AB}}$ \\
\hline & MT 3 mM & $40.55 \pm 2.80^{\mathrm{bAB}}$ & $41.50 \pm 2.13^{\mathrm{B}}$ & $37.85 \pm 1.96^{\mathrm{bA}}$ & $37.65 \pm 2.27^{\mathrm{A}}$ \\
\hline & MT 4 mM & $36.85 \pm 1.73^{\mathrm{aAB}}$ & $39.65 \pm 3.38^{\mathrm{B}}$ & $34.25 \pm 2.28^{\mathrm{abA}}$ & $36.55 \pm 2.76^{\mathrm{AB}}$ \\
\hline & MT $5 \mathrm{mM}$ & $36.70 \pm 2.16^{\mathrm{AB}}$ & $38.30 \pm 3.14^{\mathrm{B}}$ & $33.80 \pm 1.96^{\mathrm{aA}}$ & $34.45 \pm 1.68^{\mathrm{AB}}$ \\
\hline
\end{tabular}

Within columns means with different letters $(a, b, c, d)$ differ significantly $(P<0.05)$

Within rows means with different letters $(\mathrm{A}, \mathrm{B}, \mathrm{C}, \mathrm{D})$ differ significantly $(P<0.05)$

2015). Moreover, melatonin protects the mitochondria and plasma membrane from the free radical and leads to higher mitochondrial membrane potential, cell viability, membrane fluidity, acrosomal integrity and reduced lipid peroxidation (Garcia et al., 1997). Seasons are also influenced on the LPO production and antioxidant concentration as higher antioxidant was reported in winter as compared to summer season and higher LPO was in summer than in winter season in semen of Tharparkar bull (Rajoriya et al., 2013).

Melatonin has improved the mobility and velocity parameters in the present study as because of its interaction with calmodulin (Benitez-King and Anton-Tay, 1993) which in turn influences cytoskeletal elements of sperm and impacted higher sperm motility and velocity. Thus melatonin protects the sperm from stress and damage during the processing of dilution, extension and preservation. It has been speculated that melatonin is being produced in the ovary served as the activating and chemoattractant agent that aids hyperactivation of sperm leads to increased mobility and velocity to reach the fertilization site (Fujinoki, 2008). In the present study also indicated the optimum dosage of MT was $3 \mathrm{mM}$ that may be the optimum concentration of MT secreted by the female reproductive tract and/ or ovary for higher mobility and velocity for reach to site of fertilization and fertilization and to confirm this, need to estimate the concentration of melatonin in the liquids secreted in female reproductive tract and organ. Similarly in the present study, MT $3 \mathrm{mM}$ as an optimum dose to preserve the semen in liquid state.

Enhanced effect of MT on sperm motility and velocity parameters may be due to it increases ATPase levels (Chen et al., 1994), inturn increases ATP production which is the main source energy used by the sperm flagellum to initiate and activate forward progressive motility and different velocity parameters (Burger et al., 1991). Melatonin also stimulates cellular influx of $\mathrm{Ca}^{2+}$ into sperm cells enhancing their motility (Delgadillo et al., 1994). Calcium and its channels control the transition from symmetric to asymmetric flagella waveforms $(\mathrm{Si}, 1997)$ and calmodulin acts 
as an intracellular regulator of $\mathrm{Ca}^{2+}$ function and have been identified both in the head and flagellar parts of spermatozoa (Tash and Means, 1983) and are believed to be a major signal transducer in $\mathrm{Ca}^{2+}$ regulating motility. Calmodulin antagonist or lack of melatonin caused a reduction in VCL and ALH and it is related with mitochondrial membrane potential and mobility \& velocity of the spermatozoa (Ahmad et al., 1996). These results suggested that melatonin has enhanced the regulatory role of $\mathrm{Ca}^{2+} /$ calmodulin pathway in sperm motility and velocity parameters including VCL and ALH in liquid storage of mithun semen. Moreover, melatonin has improved the mobility and velocity through act on the cyclic AMP (cAMP) stimulator (Yung et al., 1995) and cAMP stimulates sperm motility via its direct action on the axoneme of the tail (Lindamann, 1978) or indirectly through acting on the cell membrane as secondary messenger (Garbers and Kopf, 1980). Thus the melatonin treated sperm has higher motility and velocity parameters in the present study.

Melatonin increased the sperm mobility and velocity attributes in the present study as because melatonin decreased significantly sperm abnormalities and acid phosphatase level during preservation in the extender (Mamdouh et al., 1996) as it can pass into the cell membrane and protects mitochondria and DNA from free radical and ROS damaging effect through its potent antioxidant and anti-aging effects on the cells (Poeggeler et al., 1993). Moreover, melatonin lowers the levels of acid phosphatase enzyme as it is considered as an indicator of cellular death or damage or poor integrity of membrane (Moss and Henderson, 1993). Thus melatonin has improved sperm progressive motility as it has decreasing effect on the phosphatase enzyme release and leakage from sperm cells during preservation (Mamdouh et al., 1996).

The different effects of the different levels of melatonin might be explained according to the report of Ashrafi et al. (2011), Perumal et al. (2013) and Perumal et al. (2015) showed that the excessive amount of antioxidants caused high fluidity of plasma membrane above the desired point, making sperm more prone to acrosomal damages. Moreover, the concentration of antioxidants added to extender should be considered since high dosage of antioxidants may be harmful to spermatozoa due to the change in physiological condition of semen extender. In mithun, survival, mobility and velocity of spermatozoa were increased as the dosage of antioxidant added to extender increased. However, the antioxidant dosage higher than required amount was toxic to spermatozoa (Perumal et al., 2013; Perumal et al., 2015). The over expression of melatonin may reflect a defect in the development or maturation of spermatozoa, as well as sperm cellular damage, resulting in decreased sperm fertilization potential (Ashrafi et al., 2013). Similarly, in the previous study, increasing dosage of melatonin, more than $3 \mathrm{mM}$ affected the seminal as well as biochemical parameters in mithun semen preserved with TEYC extender (Perumal et al., 2013; Perumal et al., 2015). At the same time, less dosage rate also affected the sperm parameters. But as per the dosage, these velocity and mobility parameters were increased upto $3 \mathrm{mM}$ then decreased to $5 \mathrm{mM}$.

The improvement of semen quality due to addition of exogenous melatonin recorded in the present study was previously reported (Casao et al., 2010; Ashrafi et al., 2011; Ashrafi et al., 2013; Perumal et al., 2013; Perumal et al., 2015). Moreover, the addition of exogenous melatonin was significantly improving the percentages of DNA morphology, sperm viability and intact plasma membrane (swelling tails) especially at the optimum $(3 \mathrm{mM})$ level of melatonin was reported in the previous study (Perumal et al., 2013; Perumal et al., 2015). The highest percentages of intact plasma and acrosomal membranes which were found in the previous experiments due to $3 \mathrm{mM}$ melatonin may be the reason for better motility and velocity in the present study (Perumal et al., 2013; Perumal et al., 2015; Ashrafi et al., 2013).

In the present study, the concentration of MT decreased in serum of summer season because the thermo stress and long photoperiod leads decreased production of melatonin and also affects the normal function of testes and accessory sex glands as similar in cryptorchid testes (Ahotupa et al., 1992) and summer stressed animals. In the previous study, leakage of intracellular enzyme was lowered in semen preserved at $3 \mathrm{mM}$ of melatonin at liquid storage period indicated that it stabilised the membrane integrity of acrosome, plasma, mitochondria and flagella of the sperm (Perumal et al., 2013; Perumal et al., 2015) and was lower in spring and autumn season than summer season as the summer hot and winter cold stress affect the function of accessory glands, seminal vesicle and epididymis that leads to poor plasma membrane and acrosomal membrane stability leads to more leakage of intra cellular enzymes in summer season. Moreover, functions of these glands depend upon the androgen; summer stress cause secretion of androgen is affected. Thus the sperm from summer season has poor quality, stability, motility and velocity in the present study.

In the present study, velocity and mobility profiles were higher in spring and winter seasons, the seasons have short day light. This indicates that during this short day season, there was more secretion of melatonin in mithun and protected the seminal, biochemical and antioxidant parameters along with stimulation of hypothalamus to secrete more GnRH followed by high semen production. Moreover, there may be high variation in melatonin secretion and concentration throughout the year in mithun blood and seminal plasma that could partly explain the differences in 
sperm quality and fertility observed between the different seasons (Ashrafi et al., 2013) in mithun species. The concentration of melatonin in different seasons also indicated that higher value was observed in winter and spring seasons than in summer season and thus may be the reason, the semen from spring and winter season has higher velocity and motility. Similarly, in mithun cows, short day may induce secretion of melatonin; stimulate $\mathrm{GnRH}$ secretion followed by expression of heat, breeding, conception and calving. But in the present study, we didn't measure the concentration of melatonin and other reproductive hormones of female animals in different seasons. However, in the previous study, highest calving rate in mithun was from November to February (winter season) followed by August to October (autumn season) indicated most of the breeding was taken during the winter and spring seasons (November to April) than in summer season (May to July) (Perumal et al., 2015).

In this study, improvements were observed in sperm velocity and motility in dose dependent manner in different seasons by means of the antioxidant property of melatonin. Thus it may protect the spermatozoa during preservation and enhancing the fertility in this species at $3 \mathrm{mM}$. Further, semen production and effect of melatonin on these CASA parameters were differed among the seasons and were higher in spring season followed by winter and autumn season whereas lowest in the summer season. From this it was concluded that collection and preservation of semen should be conducted during spring and winter season for artificial insemination but more suitable breeding season for mithun from winter to spring season (November to April). Future, ultra-low temperature sperm preservation/cryoprotective studies and correlated study with endocrinological profiles at different seasons are warranted to confirm the present findings.

\section{ACKNOWLEDGEMENT}

This research work was supported by a grant from the Department of Biotechnology, Government of India, New Delhi for the project entitled "Evaluation of melatonin as fertility marker in Mithun (Bos frontalis) bulls: Effect on circadian rhythm and seasonal variation in semen quality parameters".

\section{CONFLICT OF INTEREST}

None of the authors have any conflict of interest to declare.

\section{AUTHORS CONTRIBUTION}

Perumal Ponraj: Plan of work, execution, analysis of data and manuscript preparation; Kishore Kumar Baruah: Plan of work, technical assistance, analysis of data and manuscript preparation; Kobu Khate: Technical assistance and analysis of data; Neeraj Srivastava: Manuscript preparation and correction; Jeetendra Singh Rajoriya: Lab work assistance and Sukkum Chang: Lab work assistance.

\section{REFERENCES}

-Acuna-Castroviejo D, Lopez LC, Escames G, Lopez A, Garcia JA, Reiter RJ (2011). Melatonin-mitochondria interplay in health and disease. Curr. Top. Med. Chem. 11: 221-240. http://dx.doi.org/10.2174/156802611794863517

-Ahmad K, Bracho GE, Wolf DP, Tash JS (1996). Regulation of human sperm motility and hyperactivation components by calcium, calmodulin and protein phosphatases. Arch. Androl. 35: 187-208. http://dx.doi. org/10.3109/01485019508987871

-Ahotupa M, Huhtaniemi I (1992). Impaired detoxification of reactive oxygen and consequent oxidative stress in experimentally cryptorchid rat testis. Biol. Reprod. 46: 1114-1118. http://dx.doi.org/10.1095/biolreprod46.6.1114

-Akhter S, Rakha BA, Ansari MS, Andrabi SMH, Ullah N (2011). Storage of Nili-Ravi buffalo (Bubalus bubalis) semen in skim milk extender supplemented with ascorbic acid and $\alpha$-tocopherol. Pak. J. Zool. 43(2): 273-277.

-Ashrafi I, Kohram H, Naijian H, Bahreini M, Poorhamdollah M (2011). Protective effect of melatonin on sperm motility parameters on liquid storage of ram semen at $5^{\circ} \mathrm{C}$. Afr. J. Biotechnol. 10(34): 6670-6674.

-Ashrafi I, Kohram H, Ardabili FF (2013). Antioxidative effects of melatonin on kinetics, microscopic and oxidative parameters of cryopreserved bull spermatozoa. Anim. Reprod. Sci. 139(1-4): 25-30. http://dx.doi.org/10.1016/j. anireprosci.2013.03.016

-Benitez-King G, Anton-Tay F (1993). Calmodulin mediates melatonin cytoskeletal effects. Experientia. 49: 35-41. http://dx.doi.org/10.1007/bf01923944

- Burger B, Vander Horst G, Menkveld R (1991). Relationship between biochemical markers and fertilization in vitro. Presented at the Annual Reproductive Biology Work Seminar, Pretoria, South Africa.

- Casao A, Cebrián I, Assumpcao ME, Pérez-Pé R, Abecia JA, Forcada F, Cebrián-Pérez JA, Muino-Blanco T (2010). Seasonal variations of melatonin in ram seminal plasma are correlated to those of testosterone and antioxidant enzymes. Reprod. Biol. Endocrinol. 8(1): 59. http://dx.doi. org/10.1186/1477-7827-8-59

- Chen L, Kumar P, Reiter RJ, Tan DX, Manchester LC, Chambers JP, Poeggeler B, Saarela S (1994). Melatonin prevents the suppression of cardiac $\mathrm{Ca}+2$ stimulated ATPase activity induced by Alloxan. Am. J. Physiol. 267: E57-E62.

-Delgadillo LH, Tay FAA, King GB (1994). Effect of melatonin on microtubule assembly depend on hormone concentration: Role of melatonin as a calmodulin antagonist. J. Pineal Res. 17: 50-58.

-Fujinoki M (2008). Melatonin-enhanced hyperactivation of hamster sperm. Reprod. 136: 533-541. http://dx.doi. org/10.1530/REP-08-0202

-Garbers DL, Kopf GS (1980). The regulation of spermatozoa by calcium and cyclic nucleotides. In: Advances in cyclic nucleotide research, Greengard P. and Robinson GA. (eds.), New York, Raven Press. Pp. 251-306. 
- Garcia JJ, Reiter RJ, Guerrero JM, Escames G, Yu B, Oh CS, Munoz-Hayos A (1997). Melatonin prevents changes in microsomal membrane fluidity during induced lipid peroxidation. FEBS Lett. 408: 297-300. http://dx.doi. org/10.1016/S0014-5793(97)00447-X

-Hardeland R, Reiter RJ, Poeggeler B, Tan DX (1993). The significance of the metabolism of the neurohormone melatonin: Antioxidative protection and formation of bioactive substances. Neurosci. Biobehav. Rev. 17(3): 347357. http://dx.doi.org/10.1016/S0149-7634(05)80016-8

-Kumar R, Jagan-Mohanarao G, Arvind R, Atreja SK (2011). Freeze-thaw induced genotoxicity in buffalo (Bubalus bubalis) spermatozoa in relation to total antioxidant status. Mol. Biol. Rep. 38(3): 1499-1506. http://dx.doi.org/10.1007/ s11033-010-0257-1

-Lindamann CB (1978). A cAMP-induced increase in the motility of demembranated bull sperm models. Cell. 13: 9-18. http://dx.doi.org/10.1016/0092-8674(78)90133-2

-Mamdouh M, Anwar GA, Megahed T, El-Deeb TM, Hasan SS (1996). The effect of melatonin on the bull liquid semen and enzymatic release in seminal plasma. Assiut. Vet. J. 35: 42-62.

-Martin-Hildago D, Baron FJ, Bragado MJ, Carmona P, Robina A, Garcia-Marin LJ Gil MC (2011). The effect of melatonin on the quality of extended boar semen after long-term storage at $17^{\circ} \mathrm{C}$. Theriogenol. 75 : 1550-1560. http://dx.doi. org/10.1016/j.theriogenology.2010.12.021

-Mathevon M, Buhr MM, Dekkers JCM (1998). Environmental, management, and genetic factors affecting semen production in Holstein bulls. J. Dairy Sci. 81: 3321 - 3330. http://dx. doi. org/10.3168/jds.S0022-0302(98)75898-9

-McEntee E (1990). Reproductive pathology of domestic mammals. Academic Press, New York. Pp. 224-251. http:// dx.doi.org/10.1016/B978-0-12-483375-3.50019-6

-Moss DM, Henderson ER (1994). Enzymes. In: Tietz Textbook of Clinical Chemistry, $2^{\text {nd }}$ edn., Burtis CA, Ashmood ER (eds.), W.B. Saunders Co., Philadelphia. Pp. 735-896.

-Perumal P, Selvaraju S, Selvakumar S, Barik AK, Mohanty DN, Das RK, Srinibas Das, Mishra PC (2011). Effect of pre-freeze addition of cysteine hydrochloride and reduced glutathione in semen of crossbred Jersey bulls on sperm parameters and conception rates. Reprod. Dom. Anim. 46 (4): 636-641. http://dx.doi.org/10.1111/j.1439-0531.2010.01719.x
-Perumal P, Chamuah JK, Nahak AK, Rajkhowa C (2015). Effect of seasons on semen production, effect of melatonin on the liquid storage $\left(5^{\circ} \mathrm{C}\right)$ with correlated study of birth rate in mithun (Bos frontalis). Asian Pac. J. Reprod. 4(1): 1-12. http://dx.doi.org/10.1016/S2305-0500(14)60049-X

- Perumal P, Srivastava SK, Ghosh SK, Baruah KK (2014). Computer assisted sperm analysis of freezable and nonfreezable mithun (Bos frontalis) semen. J. Anim. 2014: 6 pages.

-Perumal P, Vupru K, Khate K (2013). Effect of addition of melatonin on the liquid storage $\left(5^{\circ} \mathrm{C}\right.$ ) of mithun (Bos frontalis) semen. Int. J. Zool. 2013: 10 pages.

-Pieri C, Marra M, Moroni F, Recchioni R, Marcheselli F (1994). Melatonin: A peroxyl radical scavenger more effective than vitamin E. Life Sci. 55(15): 271-276. http://dx.doi. org/10.1016/0024-3205(94)00666-0

- Poeggeler B, Reiter RJ, Tan DX, Manchester LC (1993). Melatonin hydroxyl radical mediated oxidative damage and aging: a hypothesis. J. Pineal Res. 14: 151-168. http://dx.doi. org/10.1111/j.1600-079X.1993.tb00498.x

- Rajoriya JS, Prasad JK, Ghosh SK, Perumal P, Kumar A, Kaushal S, Singh M (2013). Effects of seasons on enzymatic changes and cholesterol efflux in relation to freezability in Tharparkar bull semen. Asian Pac. J. Reprod. 2(4): 280 -288. http:// dx.doi.org/10.1016/S2305-0500(13)60163-3

- Reiter RJ, Tan DX, Kim SJ, Qi W (1998). Melatonin as a pharmacological agent against damage to lipids and DNA. Proc. West. Pharmacol. Soc. 41: 229-236.

- Reiter RJ (1991). Pineal melatonin: Cell biology of its synthesis and of its physiological interactions. Endocr. Rev. 12(2): 151-180. http://dx.doi.org/10.1007/978-1-4615-3756-4_6

-Si Y (1997). Temperature-dependent hyperactivated movement of hamster spermatozoa. Biol. Reprod. 57: 1407 -1412. http://dx.doi.org/10.1095/biolreprod57.6.1407

-Tash JS, Means AR (1983). Cyclic adenosine 3', 5' monosphate, calcium and protein phosphorylation in flagellar motility. Biol. Reprod. 28: 75-104. http://dx.doi.org/10.1095/ biolreprod28.1.75

-Yung LY, Tsim ST, Wong YH (1995). Stimulation of cAMP accumulation by the cloned Xenopus melatonin receptor through G1 AND G2 proteins. FFBS Lett. 372: 99-102. http://dx.doi.org/10.1016/0014-5793(95)00963-A 